\title{
THE INSTITUTIONAL FRAMEWORK OF THE NEW FINANCIAL REGULATION MODEL IN THE EUROPEAN UNION
}

\author{
Mónica Puente Regidor \\ Universidad Complutense de Madrid
}

http://dx.doi.org/10.5209/rev_NOMA.2013.v39.n3.4832

\begin{abstract}
The economic crisis, which has been with us since 2008, has called into question the supervision and financial regulation model in the European Union (EU). The economic governing system, which was born after the creation of the European Economic and Monetary Union (EEMU), has been shown to be clearly insufficient in order to deal with the impact of the recession which has hit the twenty seven Member States of the EU. This situation has illustrated the need for a wider cooperation between the States, some supervisory institutions with a more systematic vision and a better designed and more specific financial system.

The objective of this article is to analyze the modifications which have been made to the supervision model of the European financial system, the problems which have resulted and the lines of improvement which must be studied if the intention is that the supervision model of the European financial system is going to be a trustworthy, efficient and effective model in the future.

To do this, the changes in the renovation of the financial supervision model in the EU, which have been made since 2011, will be studied. In the first place, the macro-prudential and microprudential supervision through the restructuring of the three fundamental bases of the financial system will be analyzed: banking system, market values and insurance. Secondly, a critique of the model will be carried out and the most problematic points of the system will be outlined in order to highlight areas which need improving and finally, the conclusions will be presented.
\end{abstract}

Keywords.- economic governing, financial supervision, regulation, European Union.

Código JEL: G2

\section{Introduction}

As well as announcing the depth of the economic crisis five years ago, which we continue to suffer with no clear signs of recovery, the fall of the Lehman Brothers investment bank (USA 2007) revealed to everyone the incapacity of the existing systems of supervision and regulation to prevent, control and manage the systematic effects of risk to an increasingly global World.

In November 2008, the G20 which covers the most powerful nations in the World, decided to institutionalize the Financial Stability Forum (FSF) which is a forum for debate on global financial stability after carrying out analysis on the housing boom crash in United States and the resulting global consequences. Thus, the Financial Stability Board was created in April 2009, a group which has the aim of establishing the coordination of the States and with the objective of developing and promoting the implementation of effective supervision and regulation as well as other policies in the financial sector in order to achieve financial stability.

With the creation of the FSB, the G20 had detected two problems in the base of the previous renovation of the World financial system in 2008. Firstly, the 
existing global risks make a wide coordination between the member States essential and secondly, we don't have the tools to control the global effects of the crisis.

Under these two premises, a reconstruction of the financial sector was attempted focusing on the reestablishment of a supervisory and regulatory system with three fundamental objectives; to generate transparency, increase the solvency of the financial entities and to generate an efficient protection, especially for the small investor.

The FSB guidelines are set out by the ministers and governors of the central banks of the member countries of the G20.

Of the 20 participant countries of the G20, five are countries of the EU (Germany, France, Italy, Holland, and United Kingdom) which are together with the other EU countries a supranational economic entity. That is, $30 \%$ of the composition of the European Union.

The relevance of the EU as a member and key participant of this renovation of the World financial system is crucial, despite the loss of power after the change of economic scenario and global political shift after the economic crisis.

Therefore, the EU, under the strategy of the FSB, has an essential role in the implementation of measures in order to generate an efficient and effective supervisory and regulatory system. Moreover, if we take into account that the local and economic origins of the crisis, centered in the USA has been successively transformed to the point of being converted into a European economic crisis and eventually, a political crisis in the heart of the institutions and member states of the EU.

Thus, as from 2008, the EU became conscious of the effects of not having an efficient and coherent economic management and of the necessity of a greater coordination of economic policies. Prior to the crisis, the economic policy was principally based on consensus and without obligatory norms and rules except that defined political budget within the framework of the Growth and Stability Pact (GSP). A GSP which was not really adhered to by members of the Euro zone (as from the March 2005 reforms), despite it being legally binding.

The EU decided to improve its economic management system as from 2011, that is, the institutions system and established procedures in order to achieve the objectives of the Treaty in the economic field and as a consequence, improve the coordination of the economic policies with the aim of encouraging economic and social progress for the citizens of the EU.

The changes made as from 2011 were focused on the updating of the existing organizations and the adoption of other new ones with a view to establish a coordination and re-forced vigilance of the budgeted policies and macroeconomics. For that, a re-modeling of the three large blocks of European management was planned:

Firstly, the creation of a strengthened economic agenda with wider supervision by the EU and to have the objective of a stricter EU vigilance of economic budget policies(within the GSP framework). Thus, the European Semester was created in order to debate economic priorities and yearly budget, the political objectives in agreement with the 2020 European Strategy and the commitments 
made by the member countries who participate in the Pact through the Euro Plus.

Secondly, the coordination of different actions to safeguard the stability of the Euro. In this sense, the European Mechanism of Financial Stabilization and Financial Stability Fund, created in 2010 to cope with the sovereign debt crisis, were substituted by a more permanent mechanism, the European Stability Mechanism. Under the consideration of the risks faced in the EU environment, they are possibly not provisional but structural, bearing in mind the problems of European integration.

Thirdly, actions to renew the financial system. Continuing the FSB strategy and to provide a transparent system, solvency of the financial entities and protection for the retail investor. To achieve these objectives, the EU has created new norms and organisms in order to prevent problems and assure that it regulates and supervises the activity of financial agents correctly. And secondly, actions to guarantee that the European banks have sufficient capital reserves to support the turbulence which could threaten the financial system in the future, to an extent that they can continue operating and offering credits to homes and companies. $^{1}$

All of the above was inspired by the basic principle which guides the strategy of the FSB; the economic coordination and policy as a fundamental element to cope with a global World, a coordination which has to be even wider and more effective among countries of the EU who theoretically, implement an integration project which is not only economic but also political in the long term.

The objective of the project is to carry out an analysis of the supervision and regulation of the financial system of the EU primarily, as from 2011, with the fundamental element of the renewing of the economic management model which has been implemented to improve the coordination and economic policy among European member states.

In order to carry out this goal, the Project is structured in the following way: firstly, a revision of the theoretical framework and secondly, the analysis of the current supervision and regulation system in the EU zone. As a continuation, we will provide a critique of this system and suggest possible areas of improvement in order to reach the proposed objectives in an efficient and effective way and lastly, we will establish some final conclusions.

\section{State of the question}

The issue of financial supervision and regulation has been widely dealt with, fundamentally through business and journalistic forums. Generally found in the press through articles of opinion and information relevant to aspects of financial regulation and supervision echoing a topic which is particularly prominent in these moments. The companies which are fundamentally of a consultancy nature and lawyers offices make dossiers and reports on how new regulations

\footnotetext{
${ }^{1}$ Czulaba, M., Mitxelena, C., Puente, M. (en prensa) Hacia un nuevo modelo de Gobernanza Económica Europeo: bases para el crecimiento en Europa. 7th International Conference on Applied Economics Contemporary Issues in Economy. Growth Perspectives in Europe?. 24-25 de Mayo de 2013. Torún, Poland
} 
can affects their clients and make decisions on where the next legislative decisions and central banks could go. However, the financial supervision and regulation is a less analyzed field with respect to scientific study and academic reflection.

In part, this academic abyss comes from the success of the neoliberal paradigm, predominantly as from the mid seventies which advocated the fact that markets are efficient and must work liberally with the minimum legal restrictions possible. This fact has provoked academic debate on the creation of regulation and supervision systems of the financial system not considering the most followed line of the investigation. This does not mean that academic literature has not existed on financial risks and which argue for the necessity of an adequate regulation and supervision system as suggested by the work Amihud, $Y$ \& Lev B in 1981 or the work of Amel, D. Bares C, Panetta F and Salleo C in 2004, by De Nicoló G, Bartholomew P, Zaman J and Zephirin M in 2004 or by Demsetz, R \& Strahan P in 1997. We must not forget the work of Borio C in 2003, which was relevant but not the line of argument generally followed by the aforementioned academics.

However, the financial deregulation process during the eighties, under the premise of Milton Friedman and the Chicago School, and initially embodied by Ronald Reagan y Margaret Thatcher has been shown to have had catastrophic consequences on society. In fact, authors such as Paul Kruggman, the Nobel Economic prize winner in 2008, have indicated that one of the causes of this current international economic crisis has been the absence of regulation and supervision of the financial entities which have favored the uncontrolled risk tasking and unorthodox practices of business managers.

Thus, the FSB report in November 2008, established the necessity of improving the $q$ confidence of society in the international financial system and its quality, determining as key objectives the improvement of transparency, protection of the small investor and solvency of financial entities where financial regulation and supervision forms as the most adequate vehicle to achieve these goals.

The consequences and reflections on the origins of the crisis and fundamentally, as from the creation of the Stability Board (FSB) in 2008 and the guidelines of the $\mathrm{G} 20$ on the necessity of generating a system of regulation and supervision in order to avoid the consequences of this crisis repeating itself, has fostered an increase in academic work on the necessity of establishing an efficient and effective supervisory and regulatory system which limits the systemic risks allowing the setting of bases for solid and sustainable international recovery at that time. In this sense, it is necessary to generate a theoretical framework which lays the foundations of an international financial system which is strengthened as a result of the initiatives put into place by the international institutions. This academic framework reference does not exist however, there are numerous recent reports which have emerged and have the objective of analyzing the structure of this new regulatory and supervisory system which emerged as from 2010 as a result of the decisions of the G20. In the same way, we should highlight the work of Brunnermeier, M, Crockett, A, Goodhart C., Persaud, A. D and Shin A of 2009 titled The Fundamental Principles of Financial Regulation, in which the necessity of generating a financial regulatory system is argued for which centers on two fundamental aspects; to create a micro and macro prudential regulation in two different 
institutions and secondly, to improve the coordination between the international institutions.

Within the academic literature, we can also highlight the articles in the works of Goodhart, Kashyap, Tsiicis and Vardoulakis in 2012, where they established the so called model (GKTV), a balanced and dynamic general model which provides a conceptual framework for the analysis of macro-prudential policies. A later revision of this model by Adrian T in an article published at the end of 2012 must also be highlighted.

We have to also point out the relevant study by Crockett $A$ in 2009 , which argues for the necessity of reforms which make the regulatory system reflect the different risks through the cycle and limits the tendency for pro-cyclicity, without forgetting the interesting article by Gambacorta $L$ and van Rixtel $A$ in 2013 where some recent banking regulatory initiatives and their consequences are reviewed.

In this theoretical review, we have to mention the article by Subbarao D in 2011 in which he reminds us of the necessity of not only improving financial supervision and regulation projects but also of the relevance of evaluating which type of financial regulation we want to implement, with what objectives and at what cost.

As we can see, there is a uniform theoretical opinion on the analysis of financial supervision and regulation, fundamentally focused as from the beginning of the economic crisis. However, a necessity still exists of completing these articles with a detailed analysis of the consequences of the decisions taken on the International economy and the affected entities, the agents of the financial system as well as a more general reflection on the impact of this regulatory and supervisory system which is being created as well as the established objectives for the near future. This necessity forms the focal point of this presented piece of work.

In the next section, we will study how the financial supervisory and regulatory system has been developed in the European framework as from 2011, using the ideas and initiatives presented in this theoretical framework as a reference.

\section{The supervision and regulation of the European financial system as from 2011}

The European Union is an economic and political space which is particularly complex and in continuous development. The 27 state members who make up the European Union form part of an economic union. Of these 27, seventeen share a common currency but do not form an optimum monetary area $^{2}$. Of the ten State members which continue maintaining their sovereignty in monetary politics, three of those (the so-called "opt-outs"), United Kingdom, Denmark and Sweden, are voluntarily out of the Euro zone. That is, "for the moment" they don't want to share a common currency. The other seven countries, the "preins", a product of the latest additions in 2004 and 2007, have the intention of

\footnotetext{
${ }^{2}$ Donges, B. J (2012) Crisis europea y el reto de una gobernanza económica eficaz Círculo de Empresarios.pág.104 Disponible en http://www.slideshare.net/circulodeempresarios/103138dongesjuergen-b
} 
joining the Euro zone with some more in favor than others, however, they do not fulfill the obligatory economic and financial requisites that the Euro countries consider necessary before entering this exclusive club of 17 countries.

Despite the advances in setting up the European Union in a unique market, in reality it does not exist quite like this. Theoretically, with the Single European Act in 1986, a unique market was created which eliminated barriers and obstacles to the free movement of people, goods, services and capital. And, as from 1992, the EEC (European Economic Community) with the Maastricht Treaty was institutionalized as a sole market with the creation of the Euro. However, despite these efforts, the European Union continues to not be a unique financial entity. A progressive reconciliation exists but at the same time, juridical and political obstacles and barriers continue existing ${ }^{3}$ which do not allow us to view EU as a unique financial area.

As a result, the EU is not a unique financial market and until 2011, it did not have a unique system of financial supervision. In this same way, this creates a problem for the harmonization of the juridical norms because the controls have been basically national since 2011 .

In the FSB report in October $2011^{4}$, with the objective of generating transparency, solvency of the financial entities and protecting the small investor, the G20 established the necessity of creating more global controls through macro-prudential supervision. In fact, the FSB established itself as a systematic risk supervisor at an International level. These considerations are extrapolated by the FSB members to their legislations, shaping their own supervision models.

At an International level, three supervision models basically exist. ${ }^{5}$ The sectorial model, belonging to the countries of the Mediterranean Arc - France, Portugal, Greece and Spain, where the entities are characterized y their typology and each one is in charge of their regulations, both in the supervision of their solvency and their conduct. Understanding by solvency supervision "...that whose objective is to assure the solvency of the financial entities which would mean the analysis and valuation of all of those questions related to the entity which could impact the future or current solvency. And the supervision of conduct or that which refers to the necessity of assuring some adequate market practices, avoiding irregularities of information and in general, regulate the due relation which must exist between the financial entities and their clients" ${ }^{\prime 6}$. In opposition of this system, we find the unified system which belongs to the United Kingdom and USA ${ }^{7}$ where a conduct and solvency supervision has been established in one sole organization where the Central Banks have a very

\footnotetext{
${ }^{3}$ Puente, M. (2011)Towards a single Stock Exchange in EMU? China_USA Business-Review 10 (11), 1061-1079

${ }^{4}$ Progress report from the FSB, the IMF and BIS on macroprudential policy tools and frameworks. Progress Report to G20. 27 Octubre 2011 http://www.imf.org/external/np/g20/pdf/102711.pdf

${ }^{5}$ Davies H y Green D (2009) Regulación financiera mundial. Barcelona: Paidós pág 153

${ }^{6}$ Guerra Azcona I (2009) Conducta y solvencia: visión crítica del sistema de doble supervisión. Ponencia Ministerio de Justicia.pag.4 Disponible en http://www.mjusticia.gob.es/cs/Satellite/1292338910071?blobheader=a.

${ }^{7}$ Goodhart, C (2001) The organizational structure of banking supervision. Financial Stability and Central Banks. Londres. Reino Unido: Routledge
} 
active role ${ }^{8}$. And, on the other hand, we find the functional system, belonging to Holland and Australia also known as "twin peaks" which attributes the supervision of conduct and solvency of all of the financial entities to distinct organizations. ${ }^{9}$

The European debate on what should be the supervision model to be implemented is not new. From the creation of the Euro and fundamentally, from the Plan of Action of the Financial Services (1999-2005) and the White Paper on Financial Services Policy (2005-2010) the role of the European financial institutions in the area of macro and micro systematic supervision has been discussed.

The Lamfalussy report ${ }^{10}$ in 2006 and the Larosiere report in 2009, established the following fundamental lines which respond to the supervisory system until 2011. Firstly, the difference between macro- supervision (European Council of Systematic Risk) and micro- supervision (European system of Financial Supervisors). In the second place, the ECB is left out of the supervisory functions. And in third place, the sectorial structure is maintained in micro supervision through the supervision committees with strengthened competency $^{11}$.

As from 2011, the new supervisory and regulatory architecture of the European financial system is left in the following forma:

The supervisory and regulatory system is produced to comply with the following fundamental objectives of an international and European regulatory and supervisory system which are: to make the system transparent, control the solvency of the financial entities and to protect the small investor.

The basic principles which support these objectives are basically two, the consideration of the risks which we face being systematic and thus, an essential requisite is to improve the supervision and regulation at both International and European level, within the EU framework. In second place, the relevance of the responsibility of corporate management and the ethical considerations of the business management team as a key element of the correct functioning of the financial system.

With these two principles in mind, and with similar objectives to the FSB at a global level, a macro-prudential supervisor was created in the EU, the European System Risk Board (ESRB), which, according to the regulations of its creation, ${ }^{12}$

\footnotetext{
${ }^{8}$ Goodhart, C., Kashyap, K., Tsomocos, D. y Vardoulakis, A. (2013). An integrated framework for analyzing multiple financial regulations. International journal of Central Banking, 9 (Supp.1), 109-144.

${ }^{9}$ Mardomingo Cozas, J. y Mínguez Hernández, F. (2009) Hacia un nuevo esquema de supervisión financiera en España. Revista de Mercados de Valores, 4, 290

${ }_{10}$ Informe Franq del ECOFIN en mayo de 2006

${ }^{11}$ Martínez-Pardo del Valle, R. y Zapata Cirugeda, F. (2012) Informe y conclusiones del Observatorio sobre la Reforma de los Mercados Financieros Europeos Papeles de la Fundación (46) Ed. Fundación de Estudios Financieros.

Disponible en http://www.fef.es/new/index.php?option=com_k2\&view=item\&id=154:46observatorio-sobre-la-reforma-de-los-mercados-financieros-europeos-2012\&ltemid $=145$

${ }^{12}$ Reglamento (UE) no 1092/2010 del Parlamento Europeo y del Consejo, de 24 de noviembre de 2010, relativo a la supervisión macroprudencial del sistema financiero en la Unión Europa y por el que se crea una Junta Europea de Riesgo Sistémico. Directiva 2010/78/UE del Parlamento Europeo y del Consejo, de 24 de noviembre de 2010, por la que se modifican las
} 
has the objective of preventing and alleviating the systematic risks which could compromise the financial stability of the European Union. In order to achieve this objective, the ESRB must define and assemble the necessary information to identify the risks and secondly, issue alerts and make them public when necessary and finally, establish the necessary measures to manage the risks.

On the other hand, three micro-prudential supervisory organizations were created which correspond to the three pillars of the financial system; credit companies, market and investment services and insurance which are the European Banking Authority (EBA) ${ }^{13}$, the European Insurance and Occupational Pensions Authority (EIOPA) ${ }^{14}$ and the European Securities Markets Authority (ESMA) $)^{15}$.

These three institutions are strengthened by the Joint Committee of European Supervisory Authorities and the Supervision Authorities of the State members of the European Union.

These Supervision Authorities have two common bodies: the Joint Committee of European Supervisory Authorities, in charge of cooperating with these financial conglomerates, accountancy and auditing services, Micro-prudential analysis, retail investment products, measures against money laundering and the exchange of information with the Joint Committee of European Supervisory Authorities.

The first Supervisory Authority is the European Banking Authority. The EBA -is formed, according to the regulations of its creation, to generate greater integration and stability of the European banking sector and a more global and integrated supervision.

Therefore, the fundamental objective of the EBA is to protect the stability and efficiency of the banking system, with the emphasis placed on the protection of the total potential systematic risk which affects the financial entities. This, in turn, could influence the collapse or bad functioning of the financial system or the economy as a whole. It is also charged with the supervision of the credit entities, financial conglomerates, investment companies, payment entities and electronic money entities.

Directivas 98/26/CE, 2002/87/CE, 2003/6/CE, 2003/41/CE, 2003/71/CE, 2004/39/CE, 2004/109/CE, 2005/60/CE, 2006/48/CE, 2006/49/CE y 2009/65/CE en relación con las facultades de la Autoridad Europea de Supervisión (Autoridad Bancaria Europea), la Autoridad Europea de Supervisión (Autoridad Europea de Seguros y Pensiones de Jubilación) y la Autoridad Europea de Supervisión (Autoridad Europea de Valores y Mercados) Texto pertinente a efectos del EEE [Diario Oficial L 331 de 15.12.2010]

${ }^{13}$ Reglamento (UE) $n^{\circ}$ 1093/2010 del Parlamento Europeo y del Consejo, de 24 de noviembre de 2010, por el que se crea una Autoridad Europea de Supervisión (Autoridad Bancaria Europea)

${ }^{14}$ Reglamento (UE) n¹094/2010 del Parlamento Europeo y del Consejo, de 24 de noviembre de 2010, por el que se crea una Autoridad Europea de Supervisión (Autoridad Europea de Seguros y Pensiones de Jubilación), se modifica la Decisión no 716/2009/CE y se deroga la Decisión 2009/79/CE de la Comisión

${ }^{15}$ Reglamento (UE) $n^{\circ} 1095 / 2010$ del Parlamento Europeo y del Consejo de 24 de noviembre de 2010 por el que se crea una Autoridad Europea de Supervisión (Autoridad Europea de Valores y Mercados), se modifica la Decisión $n^{\circ}$ 716/2009/CE y se deroga la Decisión 2009/77/CE de la Comisión. Decisión 2001/528/CE de la Comisión de 6 de junio de 2001 por la que se establece el Comité Europeo de Valores 
In order to achieve these goals, the EBS has the following instructions: to develop projects and technical norms of regulation and execution, to issue guidelines and recommendations, construct a database (with centralized access) of the financial entities in the area of their competence.

The second institution of supervision is the European Insurance and Occupational Pensions Authority (EIOPA). The EIOPA looks to reestablish the confidence of Europeans and prevent the destabilization of the World financial system in the field of securities and retirement pensions. The EIOPA acts in the field of activities of insurance and reinsurance companies; the financial conglomerates; employment pension funds; insurance intermediaries; business management; auditing and financial information.

Finally, the third authority of supervision; the European Securities Markets Authority (ESMA). The ESMA has the intention, according to its regulations, of reestablishing the confidence of Europeans and preventing the risks of destabilization of the World financial system in the sector of securities.

The ESMA basically affects the area of the activities of societies which offer investment services; business management; auditing of accounts and financial information.

In addition, the ESMA has, in this way, assigned functions of supervision of qualification agents.

The debate on the credit qualification agents is also in the base of the reorganizing of the European financial system. The credit qualification agencies also have a significant role in a complex and globalized market. This role comes generated, in a large part, by the privileges given to them by the States by their regulation.

Despite the failure of its performance in distinct cases like Enron, Wordcom or Parmalat, etc, its lack of anticipation and its errors when granting points to companies that did not deserve them, allowing them to continue to have considerable authority in the markets.

On the other hand, it has been proposed by the FSB and G20 that they should be subject to regulation with this regulation being considered deficient in the European climate $^{16}$.

Together with the creation of these institutions of supervision, the second great pillar of the current European supervision model is the banking union which involves assigning new functions of macro-supervision to the European Central Bank (ECB) and the functions of micro-supervision with respect to the entities which are considered systematic, leaving the national supervisors the control of the local entities and the gathering of information.

Since the reunion of Ecofin on 13th December 2012 where it was agreed to advance the process of a banking union, a market agenda has been established, not only for the creation of a unique banking supervisor for the direct recapitalization of the bank which is programmed for June 2013, the establishing of a mechanism of resolution of the financial entities and the funds which guarantee common deposit accounts. In this way, the ECB will be

${ }^{16}$ Reglamento 1060/2009 y propuesta de modificación de la Comisión Europea de 15 noviembre de 2011 
established as the direct supervisor of the Banks whose assets are more than $30,000,000 €$ or $20 \%$ of the national GDP, in total, 200 of the more than 600 current EU banks:

One of the fundamental elements of this first principle of actions aimed at controlling systematic risk, which both the G20 and the EU discuss at an International level, are the systematic supervision entities. It is considered as a relevant factor in this sense for its grade of interconnection of its activities and thus, of possible infections of its risks to the rest of the system.

The debate on its regulation centers on two aspects. In the first place, on if greater requisites of capital and liquidity should be demanded and the effect that this could have on family and business credit. And in second place, to make these demands compatible with the International growth model.

As well as the systematic entities, there are four key elements we will highlight, in the debate on supervision and regulation at International level, the worry about shadow banking, the role of hedge funds, UCITS and OTC by-products as expansion elements of banking risk and control through the Basel III normative.

The first of these elements is shadow banking, which the FSB define as "the system of credit intermediation that involves entities and activities outside the regular banking system" ${ }^{\prime 17}$

The fundamental objective of the $\mathrm{G} 20$ and the EU is to establish a framework of control in this issue, currently materialized as a collection of recommendations for the States ${ }^{18}$.

On the other hand, and closely connected with shadow banking is control of the hedge funds, the OTC by-products and UCITS (alternative funds).

The regulation and supervision of these three risks, considered by the G20 as systematic, is inconclusive and influences the control and regulations, such as the gradual convergence of the developments by the USA and Europe.

The fourth element that we have to consider in relation with systematic risk is the Basle III $^{19}$ regulation at International level. The objective is to create a collection of capital and liquidity measures in order to strengthen the solvency of the banking system.

The general objective is illustrated in a collection of measures to directly demand more capital through greater intimations with respect to risk and exposure and indirectly, through a ratio of leverage and some back up capital to use in crisis situations. In addition, a better quality capital will be demanded through a more restrictive definition of ordinary capital and reserves.

\footnotetext{
${ }^{17}$ Informe Financial Stability Board (2011) Shadow Banking: Strengthening Oversight and Regulation Recommendations of the Financial Stability Board Disponible en http://www.financialstabilityboard.org/publications/r_111027a.pdf

${ }^{18}$ FSB (2012) Streghtening oversight and regulation of shadow banking y también en Green Paper. Shadow Banking. Comisión Europea.(2012) Disponible en http://ec.europa.eu/internal_market/bank/docs/shadow/green-paper_en.pdf

${ }^{19}$ Rodriguez de Dodes, E. (2011) Las nuevas medidas de Basilea III en el sector bancario. Estabilidad Financiera(19) Ed. Banco de España
} 
The transition of Basle III began at the beginning of 2013 and will last until $1^{\text {st }}$ January 2019.

With respect to the banking sector and related with the objective of achieving a greater degree of transparency, the so called bank Stress Tests appeared which have been carried out in 2010 and 2011. The debate on these initiatives has positive and negative aspects. With respect to the positive aspects, banking conditions and the facilitating of capital have improved. However, this transparency can also have negative consequences, such as generating distrust among agents and depositors who do business with the particular financial entity. Thus, a unfavorable opinion exists towards these tests in as much as there are no homogenous criteria for all those entities where the criteria is applied and that these criteria should be more efficient, with more information on the real explanation of the results. The criticism of the evaluation that this system has received have motivated the fact that, these tests have not been repeated since 2011.

To increase the transparency in the area of markets and investment services, we can find the MiFID II Directive. MiFID has the objective of increasing competition between negotiating systems allowing new competitors to enter with less restrictions on regulated markets. However, the European Commission has understood and in this sense, explains the existence of MiFID II, these developments need new impulses to attend to the complexity of the new technological developments on trading and giving more advantages to small investors as potential beneficiary of these new platforms of negotiation.

Level II measures called Solvency II Directive, were developed in the insurance sector, with the objective of increasing transparency and strengthening risk control.

In the same way, coordination is the other key we highlight when we made reference to systematic risk. The integration of the European market infrastructures is a determining element in the new restructuring of the financial system. An example are the EMIR and Target 2 Securities projects which will become effective in 2015 and which have the objective of affirming the integration process on the structures of post-contraction to homogenize and automate the procedures.

In this sense, we find the MAD II integration project, designed to integrate European regulators from the viewpoint of improving the prevention of market abuse.

The second great principle of the current supervision and regulation model is the importance of good corporate management (increase the responsibility of the agents), controlling the salaries of company directors and also the so called proxy advisors.

Following the statement of 5th September 2009 by the Ministry of the Economy and the Governors of the Central Banks of the G20 which emphasized the fact that measures must be taken to guarantee sustainable growth and to construct a stronger International financial system through regulation of payments to the bank, which is covered by the Directive III of Capital requirements which has been transposed to the State Members. Finally, the necessity to control the proxy advisors who the National Commission of Market Values (NCMV) define 
as "entities that lend consultancy services to investors, (mainly institutions), in return for the derivative right to vote on the ownership of shares in highly valued societies" ${ }^{\prime 20}$.

Continuing with this concern for good corporate management, the European Commission designed the Green Paper in April 2011. The Green Paper constitutes the regulations of corporate management of the European Union ${ }^{21}$. In the framework of the EU, this regulation is applied to all companies who are listed on the Stock Exchange and is a combination of legislation and regulations of a non-binding nature (soft law) which includes recommendations and codes of corporate management.

\section{Review of the new financial regulation and supervision model of the European Union.}

Despite the efforts made, the report in March 2013 by the FMI (Financial System Stability Assessment) concluded that "Financial stability is not assured"22.

The supervision and regulation model at an International level and fundamentally, in the framework of the European Union, presents many weak points ${ }^{23}$ which, if not resolved, could cause a failure in achieving the proposed objectives and thus, we will not get an adequate answer to the current necessities of financial system control at a global and regional level.

The main criticisms of the current model of control and supervision of the European financial system would be: at International level, the excessive regulations in a global framework of competitive de-regulation and the lack of coordination between the FSB and the JERS. At a European level, we can highlight a lack of definition and juridical security of the supervision and control model, integration problems and double supervision between the Member States and the time taken in implementing the model.

Firstly, an excess of regulatory procedures can be observed in an area of competitive de-regulation between International financial markets. In their January 2013 report, the FSB pointed out that the increase in regulatory charges could lead to an increase in shadow banking ${ }^{24}$.

This issue has developed into the big current debate, especially when the EU discussed the viability of the "off-shore tax havens" at both community and global level.

20 CNMV (2012) Informe evaluación comportamiento Proxy Advisors Disponible en http://www.cnmv.es/DocPortal/Publicaciones/Grupo/InformeProxyAdvisors.pdf

${ }^{21}$ Comisión Europea (2011) Libro verde. La normativa de gobierno corporativo de la UE. Disponible en

http://eurlex.europa.eu/LexUriServ/LexUriServ.do?uri=COM:2011:0164:FIN:ES:PDF

22 Informe FMI (marzo 2013) Disponible en

http://www.imf.org/external/pubs/ft/scr/2013/cr1375.pdf

${ }^{23}$ Goodhart, C., Kashyap, K., Tsomocos, D. y Vardoulakis, A. (2013). An integrated framework for analyzing multiple financial regulations. International journal of Central Banking, 9 (Supp.1), 109-144.

$\begin{array}{lllll}24 & \text { Informe } & \text { FSB } & \text { (2013) }\end{array}$

http://www.financialstabilityboard.org/publications/c_130129xx.pdf 
At the G20 meeting in 2008, it was agreed to eliminate tax havens at an International level, which included the work done by the Financial Action Task Force on the subject of tax evasion, prevention of laundering of capital and financing of International terrorism ${ }^{25}$. Moreover, a meeting of the EU Ministers of the Economy was held in April 2013, due to the necessity of achieving resources and avoiding tax evasion and taking measures against investments in offshore tax havens.

The EU is made up of reluctant State Members such as Luxembourg and Austria however, the five main countries of the EU have agreed to set up a pilot project of automatic exchange of banking information on details of nonresidents.

This environment of competitive de-regulation, also slows down the setting up of reforms to avoid generating too much regulatory burdens on the companies. This lack of agility in implementing the regulations is viewed by the State Members as an advantage in avoiding that the economic agents comply with the regulation and give themselves an advantage over companies who do comply with them. An example of which, is the refusal of London to follow the dates agreed to implement the regulatory measures in agreement with the European Councils and in this way, that the inexistence of regulation could give them an competitive advantage over those who have implemented them.

Another criticism is the lack of coordination between the FSB and the JERS, macro-prudential supervision organizations at distinct levels but which do not show any cohesion in their actions.

One of the aspects where the need for action is highlighted, as was pointed out at the G20 meeting in 2008, is that answers must be global and as such, a wider cooperation between International supervisory institutions is necessary. In order to control the systematic risks, collective actions are required. However, in reality a lack of communication between the International and European supervisors exists. In fact, institutional cooperation channels between the FSB and JERS do not exist. This lack of coordination could detract from the actions that are taken by whichever of the supervisory institutions.

In second place, the lack of definition at European level and juridical security of the European model of financial supervision and regulation is one of the most active criticisms.

The reality lies in the extreme change and the fact that the legislators act $a$ posteriori, this produces a disadvantage. The most immediate consequence, in these moments with a system undergoing a complete review, is the uncertainty created for the lack of definition of the obligations which the economic agents must abide by.

A clear example is the application of determined regulations like the MiFiD directive, of which, there are many doubts on its range. It is currently, applied to the banking sector and investment services but debate exists on its application to the securities sector.

\footnotetext{
${ }^{25}$ Nuñez Ramos, S (2010) La respuesta a la crisis financiera internacional: medidas de estabilización financiera y estrategias de salida. Presupuesto y Gasto Público 59/2010 pp 23-37 Instituto de Estudios Fiscales
} 
On the other hand, this uncertainty increases due to the lack of juridical security which causes the transitory regulations. An example is that before finishing the Basle II the transition was made to Basle III, the same happened with MiFiD to MiFiD II or MAD to MAD II.

These types of transitions make the economic agents create doubts on the different applications of the regulations.

Another criticism directed at the configuration of the European model, is the lack of bigger competition of the institutions of supervision fundamentally, the sanctioned capacity of the supervisory organizations. The fundamental tool of the JERS are the recommendations however, they do not have coercive value. Ultimately, the question would be; who is forced to comply in a preventative framework? This would mean an important limitation to the effectiveness of the system. In the end, it is highlighting the fact that the economic management model in the EU needs a complete review of the definition of obligation of the compromises and the sanctioned mediums.

Another factor related to the previous criticism, is the lack of integration of the EU markets, the consequences associated to the inexistence of a unique financial market. Let us take as an example, the existing differences between the supervision model which the United Kingdom is following and the implementation that the Euro zone is configuring.

The third criticism comes from the slow pace of the remodeling of the system and that not all of the elements of the system are being given the same level of importance.

The creation of the banking union does not have a chance of complying with the set time limits, among other things, due to the unwillingness (specifically of Germany) of complying with the changes which were introduced to the functioning of the EU as a restructuring of the Treaties. This means that all of the Member States should pass the bill internally. This causes a considerable delay to procedures which means that the recapitalization of the Banks, programmed for June 2013, will now need to be put back.

Furthermore, the banking sector is being prioritized given that it is the sector most affected by the crisis, followed by reforming markets and investment services. However, the securities sector has not been prioritized and the developments in control and supervision are slower than those applied to the banking sector and investment services.

This lack of agility in carrying out the reforms also originates from the creation of the EU. The taking of decisions in the heart of the community institutions is complex and very slow however, markets demand quick and conclusive answers, a situation which totally clashes with the reality of the EU, without a single voice and with multiple problems on agreeing on which are the relevant aspects to deal with.

After having defined the supervision model and looked at the most significant criticisms, we consider the main areas for improvement should be;

Firstly, better coordination between the supervisory organizations, that is, FSB and JERS, and between the supervision of the National institutions of the State Members and the communities with supra-national competition. The current 
implementation of supervisory structures within the State Members, with the Spanish example of, after the endowment to the General Direction of Supervision of new inspection groups in April 2013 and adapting itself to the Memorandum of understanding of conditions of political finance as written in Brussels, creating a new supervision scale which increases the complexity of the European supervision structure and nevertheless, cooperation mechanisms have not been produced among the different supervision levels.

Secondly, a better integration of the financial markets fundamentally, in the case of the EU. A progressive harmony of the procedures is happening however, juridical barriers and political obstacles continue to exist, which impede the idea of a unique financial market within the EU framework.

In the third place, and particularly related to the previous question, it is essential to give more functions and power to the supervisory organizations above the State Members, an example of which are the demands in relation to the $\mathrm{ECB}^{26}$.

In this sense, the State Members are unwilling to hand over the delegation of power of new instruments to the ECB however, they have given them the responsibility of unique banking supervision. That is, competition has been granted but they have avoided giving them the necessary power and tools to exercise this power. The direct banking recapitalization of the bank and the funds which guarantee common deposits should be a reality in order to give more coherence to the actions of the ECB.

In this sense, the fiscal union is outlined as strengthening of the advances of the banking union. A point on which, to this day, there is still no consensus between State Members.

In the fourth place, to generate structures and institutions of supervision and control which are clearer in their functioning to avoid confusion and uncertainty.

The economic agents demand institutions with clear and defined procedures in order to be able to establish strategies. The current complexity of the supervisory scheme creates uncertainty within the system.

In fifth place, to avoid the excessive bureaucracy and slowness in the taking of decisions whose most important effect is the delay in the solving of problems which require effective management such as, the regulation of hedge funds or OTC by products, distinguished as elements generated by systematic risk and whose regulation, five years after the crisis, continues to be debated.

In summary, we need a more integrated system of supervision and regulation which responds to a unique financial market in the European framework and which has multiple cooperation channels at an International level and which promotes the taking of quick decisions with a unique voice within the EU.

\footnotetext{
${ }^{26}$ Goodhart, C. y Kapoor, S. (2013) Plans for a banking union may not be enough to tackle the eurozone's economic crises (Blog Post London School of Economics and Political Science) Disponible en http://blogs.Ise.ac.uk/europpblog/2013/02/04/eurozone-banking-union-sovereignlink/
} 


\section{Conclusions}

After the completion of this study, we have arrived at the following conclusions:

Firstly, since 2008 and through the relevance acquired through the economic crisis at a global level, diverse international forums, headed by the $\mathrm{G} 20$ and the EU, consider a reforming of the supervisory and regulatory global financial system as a matter of urgency in order to prevent systematic risks.

The integration of financial markets at a global market level through the advances in the application of technology to the financial sector has made supervision based on ample coordination between the different supervisory entities and a leveling down of regulation at a national level absolutely essential. In addition, the other great principle that the system should consider regulations and principles which build good cooperative management as one of the strategic lines to follow to avoid future crisis.

In agreement with the G20, in November in 2008, that transparency, solvency of the financial entities and protection of the small investor are the objectives that the initiatives must be aimed at with this renovation of the International financial system.

In this sense, the control of the systematic entities would acquire special relevance and avoid a situation of companies acting in the shadow of the established procedures (shadow banking) due to lack of management and efficient regulation. .

In like manner, the requisites for improving the solvency of the entities, with the BASLE III regulations and the distinct regulations for controlling directors salaries and the taking of risks.

These International directives have been accepted by the EU and a regional supervision model has been extrapolated which is based on macro-prudential supervision and managed by the European Systematic Risk Board as well as a supervisory organization for each of the three pillars of the financial system: credit entities, markets and investment services and securities.

Secondly, this system should be complemented by a directing regulation for a greater integration of European financial space which would be a product of progressive harmonization of the financial regulation system at an International level. An example of which is the promulgation of the MiFiD Directive and its modification to MiFiD II, the MAD II Directive or Market abuse, or the Solvency II Directive in securities.

This supervisory and regulatory architecture is complemented by distinct supervisory models at Member State level.

In the third place, despite the efforts made in the renovation of the supervisory and regulatory system in the European financial market, this architecture has diverse weak points which need dealing with in order to achieve an efficient, effective and long lasting regulation and supervision model which would allow us to prevent future crisis. At International level, greater coordination is required between the macro-prudential supervisors in order to manage this new definition of the International financial system in a coherent way in a global market environment for competitive deregulation. 
At European level, the agents demand supervision institutions with clear and defined procedures which avoid uncertainty among the economic agents. An example of which could be better juridical security regulations.

In short, a more defined and integrated organization of power in the EU which would help us avoid incompatible supervisory procedures between State Members and which fragments the taking of decisions with the consequent effects of lack of coherence \& slowness with the sanctioned supervisory procedures.

The advance in the creation of a unique financial market in the EU is highlighted as an essential requirement in managing a system of economic management which allows the EU to establish the bases for sustainable growth and to be able to maintain its power and influence at an International level within the collective of the most competitive regions at International level.

\section{References}

Aspachs, O., Kapoor, S. y Goodhart, C. (2013) Plans for a banking union may not be enough to tackle the Eurozone's economic crisis

Disponible en http://blogs.Ise.ac.uk/europpblog/2013/02/04/eurozone-bankingunion-sovereign-link/

Comisión Europea (2011) Libro verde. La normativa de gobierno corporativo de la UE. Disponible en http://eur-

lex.europa.eu/LexUriServ/LexUriServ.do?uri=COM:2011:0164:FIN:ES:PDF

Czulaba, M., Mitxelena, C., Puente, M. (en prensa) Hacia un nuevo modelo de Gobernanza Económica Europeo: bases para el crecimiento en Europa. 7th International Conference on Applied Economics Contemporary Issues in Economy. Growth Perspectives in Europe?. 24-25 de Mayo de 2013. Torún, Poland

Davies, H. y Green, D. (2009) Regulación financiera mundial Barcelona: Paidós Comunicación

Donges, B. J (2012) Crisis europea y el reto de una gobernanza económica eficaz. Círculo de de Empresarios.

Disponible en http://www.slideshare.net/circulodeempresarios/103138dongesjuergen-b

Nuñez Ramos, S. (2010) La respuesta a la crisis financiera internacional: medidas de

estabilización financiera y estrategias de salida. Instituto de Estudios Fiscales Presupuesto y Gasto Público 59/2010, 23-37

FSB (2011) Progress report from the FSB, the IMF and BIS on macroprudential policy tools and frameworks. Progress Report to G20.

Disponible en http://www.imf.org/external/np/g20/pdf/102711.pdf

Goodhart, C (2001) The organizational structure of banking supervision. Financial Stability and Central Banks. Londres. Reino Unido: Routledge 
Goodhart, C. y Huang, H. (2000) A simple model of an international lender of last resort . Economic notes, 29 (1), 1-11

Goodhart, C. y Tsomocos, D. (2012) The challange of financial stability: a new model and its applications. Reino Unido: Edward Elger.

Goodhart, C.(2010) How should we regulate bank capital and financial products? What role for "living wills"? (Cómo Deberíamos Regular el Capital Bancario y los Productos Financieros? Cuál es el Papel de los 'Testamentos en Vida?'). Revista de Economía Institucional, 12 (23), 85-109.

Disponible en http://www.economiainstitucional.com/pdf/No23/cgoodhart23.pdf

Goodhart, C., Kashyap, K., Tsomocos, D. y Vardoulakis, A. (2013). An integrated framework for analyzing multiple financial regulations. International journal of Central Banking, 9 (Supp.1), 109-144.

Guerra Azcona I (2009) Conducta y solvencia: visión crítica del sistema de doble supervisión. Ponencia Ministerio de Justicia. Disponible en http://www.mjusticia.gob.es/cs/Satellite/1292338910071?blobheader=a.

Informe CNMV (2012) Evaluación actividad Proxy Advisors

Disponiblehttp://www.cnmv.es/DocPortal/Publicaciones/Grupo/InformeProxyAd visors.pdf

Informe Financial Stability Board (2011) Shadow Banking: Strengthening Oversight and Regulation Recommendations of the Financial Stability Board

Disponible en http://www.financialstabilityboard.org/publications/r_111027a.pdf

Informe FMI European Union: Financial System Stability Assessment (marzo 2013) Disponible en http://www.imf.org/external/pubs/ft/scr/2013/cr1375.pdf

Informe Franq del ECOFIN en mayo de 2006

Informe FSB. Strengthening Oversight and Regulation of Shadow Banking. An Integrated Overview of Policy Recommendations (enero 2013) Disponible en http://www.financialstabilityboard.org/publications/c_130129xx.pdf

Mardomingo Cozas, J. y Mínguez Hernández, F. (2009) Hacia un nuevo esquema de supervisión financiera en España. Revista de Mercados de Valores, 4, 287-299.

Martínez-Pardo del Valle, R. y Zapata Cirugeda, F. (2012) Informe y conclusiones del Observatorio sobre la Reforma de los Mercados Financieros Europeos Papeles de la Fundación (46) Ed. Fundación de Estudios Financieros.

Disponible en

http://www.fef.es/new/index.php?option=com_k2\&view=item\&id=154:46-

observatorio-sobre-la-reforma-de-los-mercados-financieros-europeos-

2012\&Itemid $=145$

Puente Regidor, M. (2011) Towards a single Stock Exchange in EMU? China_USA Business-Review 10(11), 1061-1079

Reglamento (UE) n 1093/2010 del Parlamento Europeo y del Consejo, de 24 de noviembre de 2010, por el que se crea una Autoridad Europea de Supervisión (Autoridad Bancaria Europea) 
Reglamento (UE) $\mathrm{n}^{\circ}$ 1095/2010 del Parlamento Europeo y del Consejo de 24 de noviembre de 2010 por el que se crea una Autoridad Europea de Supervisión (Autoridad Europea de Valores y Mercados), se modifica la Decisión $n^{\circ}$ 716/2009/CE y se deroga la Decisión 2009/77/CE de la Comisión. Decisión 2001/528/CE de la Comisión de 6 de junio de 2001 por la que se establece el Comité Europeo de Valores

Reglamento (UE) n¹094/2010 del Parlamento Europeo y del Consejo, de 24 de noviembre de 2010, por el que se crea una Autoridad Europea de Supervisión (Autoridad Europea de Seguros y Pensiones de Jubilación), se modifica la Decisión n 716/2009/CE y se deroga la Decisión 2009/79/CE de la Comisión

Reglamento (UE) $n^{\circ} 1092 / 2010$ del Parlamento Europeo y del Consejo, de 24 de noviembre de 2010, relativo a la supervisión macroprudencial del sistema financiero en la Unión Europa y por el que se crea una Junta Europea de Riesgo Sistémico. Directiva 2010/78/UE del Parlamento Europeo y del Consejo, de 24 de noviembre de 2010, por la que se modifican las Directivas 98/26/CE, 2002/87/CE, 2003/6/CE, 2003/41/CE, 2003/71/CE, 2004/39/CE, 2004/109/CE, 2005/60/CE, 2006/48/CE, 2006/49/CE y 2009/65/CE en relación con las facultades de la Autoridad Europea de Supervisión (Autoridad Bancaria Europea), la Autoridad Europea de Supervisión (Autoridad Europea de Seguros y Pensiones de Jubilación) y la Autoridad Europea de Supervisión (Autoridad Europea de Valores y Mercados) Texto pertinente a efectos del EEE [Diario Oficial L 331 de 15.12.2010]

Reglamento 1060/2009 y propuesta de modificación de la Comisión Europea de 15 noviembre de 2011

Rodriguez de Dodes, E. (2011) Las nuevas medidas de Basilea III en el sector bancario. Estabilidad Financiera (19) Madrid: Banco de España 